\title{
Adaptation of the Attitude Behavioural Scale section of a PATT instrument for the Omani context
}

\author{
Pablo P. Candela ${ }^{1} \cdot$ Mishack T. Gumbo $^{2}$ - Tomé A. Mapotse ${ }^{3}$
}

Accepted: 25 March 2021

(c) The Author(s), under exclusive licence to Springer Nature B.V. 2021

\begin{abstract}
This study is about the adaptation of the Attitude Behavioural Scale (ABS) section of a Pupils' Attitudes Towards Technology (PATT) instrument for the Omani context. This study is a mixed methods research design and it consists of three phases. Phase 1 of the study is reported in this article. Phase 1 started with the selection of the PATT-USA as a model to adapt, design and validate the Technology Attitude Bilingual Scale-Arabic/English (TABS) (see Annexure 1). Particular individuals we selected to critique the TABS by using a purposive sampling technique because these individuals belonged to a particular group of competent professionals. The panel of experts' aim was to establish trustworthiness of the instrument. Their evaluation was on the appropriateness of both languages, particularly that the TABS did not contain any cultural and linguistic errors that could offend the Arab culture. This panel consisted of 4 bilingual and Arab culture experts. The ABS was adapted and translated from English to Arabic. The TABS instrument consisted of an open-ended question (qualitative), demographic information, technology attitudes and language choice. The validation process was replicated from similar studies. Results show that 38 items were corrected. 27 items were classified as minor corrections, namely one to two words were corrected. 11 items were classified as major corrections, namely three to six words were corrected. These corrections are described in Annexure 2. The panel of experts' final judgement reported that the TABS was a reliable instrument to reveal Omani students' attitudes towards technology.
\end{abstract}

Keywords Technology $\cdot$ Attitudes $\cdot$ Oman $\cdot$ PATT $\cdot$ Bilingual

Mishack T. Gumbo

gumbomt@unisa.ac.za

Pablo P. Candela

ppcandela@hotmail.com

Tomé A. Mapotse

mapotta@unisa.ac.za

1 Eagle Pass, TX, USA

2 University of South Africa, P.O. Box 42308, BoordfonteinPretoria 0201, South Africa

3 University of South Africa, 467 Block M, Soshanguve 0168, South Africa 


\section{Introduction}

The aim of the study was to adapt, design, construct and validate an instrument in Arabic and English, namely the Technology Attitude Bilingual Scale (hereafter TABS-Arabic/ English) for Arab college teachers to investigate Omani college students' attitudes towards technology. The process of validating the TABS needed the input of Technology Education students; therefore, the aim of the TABS is to measure the technology attitudes of Technology students, in this case the Engineering college students in Oman. A number of PATT studies and the variations of the PATT instrument exist in different languages and environments, including Asia (Volk and Yip 1999), but the Arab world and the Arabic language have been ignored. Hence, this study fills this gap in the PATT research. About 186,000,000 Arabs speak an Arabic language (Killean 2004; Newman 2002).

The adaptation of the PATT into the TABS required minor changes in its items and structure. The need to retain the originality of the PATT's items was a major obstacle in the adaptation process. The lack of any relevant literature in the field of attitudes towards technology in Arabic and within the Arab culture context dictated a sociolinguistic analysis of items in English. This analysis was focused on the relationship between culture and language. It should be noted, however, that all the items in English were not in anyway offensive to any aspects of the Arab culture, including religion, societal and sociopolitical norms. Part of the adaptation process included the addition of instructions in Arabic and English; the clarification that the TABS was not a personal evaluative instrument, but a research tool to learn about the Arab students' attitudes towards technology. Moreover, the request for the participants' input in the meaning, wording and structure of each item in the TABS empowered them. This input is discussed in phase 3 of the project. It is therefore within the scope of this article to address this topic. Another aspect included the language level of each participant as assigned by the college and the participants' major or field of study. In sum, the most important aspect of the adaptation phase was the process of translating each item from English to Arabic and the addition of the Arabic language as a linguistic tool to answer the narrative section of the TABS. In other words, the translation of the original PATT-USA was an important part of the adaptation process in the creation of the TABS. Some of the changes in several items are used as examples in other sections of this paper.

The adaptation of the Attitude Behavioural Scale (ABS) was selected over the Concept Scale, because as adult college students, the concept of technology has already formed according to PATT research (De Klerk 1989). Furthermore, Rennie (1987) argues that age makes a significant difference in the aspects of technological concepts and attitudes towards technology. The PATT instrument in question consists of four parts with items for data gathering, which are (1) a brief description about how students perceive technology, (2) students' demographic information, (3) students' attitudes towards technology, and (4) the concept of technology. The PATT instrument comprised 100 items in English and was designed for middle school students. The adaptation of the PATT instrument to design the TABS includes Parts 1, 2 and 3, while Part 4 was omitted. Part 3 (the Attitude Behavioural Scale (hereafter ABS)) originally included six subscales, which are interest, role pattern, consequences, difficulty, school, and career.

The age of the participants was considered when structuring the TABS. Originally, the PATT 100 items were translated and it was established that the 100 items will be included in the TABS. However, Part 4 which was the Concept Section was omitted because of two factors. Firstly, items $4-11$ in the original PATT required the participants to provide 
information about family, living situation and toys. According to the Arab culture, detailed family information is considered a taboo for a young man to discuss with outside family members. The toys asked about were not part of the boys' childhood and therefore, this was irrelevant and strange. Secondly, empirical studies have reported that older students have developed a concept of what technology is. Several studies have reported problems in answering the narrative in Section One of the PATT instrument (De Klerk 1989; Rennie 1987). Another aspect of this study is the elimination of language interference. The TABS is bilingual instrument whereas the PATT is monolingual instrument; thus, the linguistic ability of the participants does not play any role in the measurement of technology attitudes.

In the design process of the instrument, models such as the PATT-USA (Bame and Dugger 1989, 1990, 1992; Bame et al. 1993), Technology Attitude Scale (Jeffrey 1993) and Technology Attitude and Concept Scale (Becker and Maunsaiyat 2002) were reviewed. The questionnaire that was designed is based on the PATT instrument Attitude Behavioural Scale (ABS) (Bame et al. 1993). The TABS was adapted to reflect a bilingual design. Moreover, this design was adapted to the Oman college-age students and included a Language Choice subscale that reflects the bilingual format of the TABS.

The objectives emanating from the above aim are stated are categorised into the three phases that characterise the development of the instrument. These are as follows:

- To adapt and translate the ABS section of a PATT instrument.

- To refine the English-to-Arabic translation of the TABS by involving a panel of bilingual experts.

- To reveal the trustworthiness of the TABS by involving a panel of experts.

The bilingual language experts explored the languages of the TABS for concision, brevity, and cultural bias.

\section{Literature review}

This review focuses on the ABS section of PATT validation studies. General PATT studies are used as a referential point. The PATT (Bame et al. 1993) instrument has been used for over 30 years. PATT research has been reported in many different settings and environments. Kim (2000) gives us a meta-review of the first 20 years of research involving the PATT. Also, Ankiewicz (2019a) reviewed the PATT instrument including all its variations used for research with children, adults and teachers, providing a solid foundation for researchers, academicians, technologists and practitioners new to the PATT studies and Technology Education. Furthermore, Ankiewicz (2019b) claims that the complex and multi-dimensional nature of the attitudes construct presents an important undertaking for scholars involved in PATT research and technology attitudes.

Validation studies were initiated with a series of studies, titled the PATT-USA (Bame and Dugger 1989, 1990, 1992; Bame et al. 1993). The validation of the TABS consulted the PATT-USA 1993 version and it was used to adapt, design and translate the ABS subscales to construct the TABS. A similar validation study was conducted by Jeffrey (1993), when he validated The Technology Attitude Scale (TAS-USA) to be used with middle school children. Firstly, Jeffrey (1993) introduced a validation process that involved a panel of experts for the establishment of content validity of the TAS. 
Secondly, Jeffrey included a pilot study using the TAS to determine problems with the instrument. Thirdly, for the establishment of instrument reliability, the TAS was administered to the participants. Furthermore, Jeffrey (1993) validated a shortened instrument and omitted the written section of the instrument.

Jeffrey's validation process and changes to the original PATT were crucial in the validation studies that followed. For instance, Volk and Yip (1999) validated and translated the PATT1-HK-Chinese, adopting the panel of experts' procedure and the omission of the written part. Volk and Yip (1999) failed to report any statistical data on their results and did not conduct a pilot study for the validation of their instrument. Volk and Yip reported on the attitudes towards technology rather than the validation results. Another validation study created a Thai version of the PATT, the Technology Attitude and Concept Scale (TACS-Thai) (Becker and Maunsaiyat 2002). Becker and Maunsaiyat adhered to Jeffrey's (1993) guidelines to validate their instrument. In this study, Part 1 of the PATT instrument was omitted but Part 4 was retained. Part 1 asked for a brief paragraph about what students think technology is. Part 4 is the Concept Scale.

Another validation study went even further in the composition of the PATT instrument, namely the PATT Short Questionnaire (PATT-SQ-Flemish) (Ardies, De Meayer and Gijbels 2013). Their validation study focused on the ABS part of the PATT and their aim was to reduce the number of items, hence PATT-SQ. Ardies et al's (2013, p. 8) PATT-SQ goal was to focus on the important role that Technological Literacy (TL) plays as a product of technology education. These scholars concluded that the PATTSQ is a valid instrument. Moreover, to confirm their validation of the PATT-SQ, Ardies et al. (2015) conducted a study to examine students' attitudes towards technology; their results reflected their earlier results. Although the PATT instrument contains a qualitative section (written part), none of the validation studies mentioned above incorporated it into their studies. Table 1 shows the validation process undertaken to validate the new versions of the PATT, including the TABS-Arabic/English.

The TABS instrument validation process included the 6 steps listed above. However, in this paper, only Step 1, 2 and 3 (as per Table 1) are addressed.

Table 1 PATT validation process (Candela, 2019)

\begin{tabular}{|c|c|c|c|c|c|}
\hline \multicolumn{6}{|l|}{ PATT Validation Process } \\
\hline \multicolumn{6}{|c|}{ Affective and Behavioural Scale (ABS) } \\
\hline Steps & Jeffrey (1993) & $\begin{array}{l}\text { Volk and } \\
\text { Yip (1999) }\end{array}$ & $\begin{array}{l}\text { Becker and } \\
\text { Maunsaiyat } \\
(2002)\end{array}$ & $\begin{array}{l}\text { Ardies et al. } \\
(2013)\end{array}$ & $\begin{array}{l}\text { This } \\
\text { study } \\
(2019)\end{array}$ \\
\hline 1. Adaptation & Yes & Yes & Yes & Yes & Yes \\
\hline 2. Translation & Yes & Yes & Yes & Yes & Yes \\
\hline 3. Panel of experts & Yes & Yes & Yes & No & Yes \\
\hline 4. Pilot study & Yes & No & Yes & Yes & Yes \\
\hline 5. Main study & Yes & Yes & Yes & Yes & Yes \\
\hline 6. Cronbach alpha value $(\alpha)$ & Yes & No & Yes & Yes & Yes \\
\hline
\end{tabular}




\section{Research methodology}

This is a mixed methods study which is complemented by the pragmatist worldview (Evans et al. 2011). The mixed methods approach was therefore deemed suitable for the validation of the TABS instrument. Since mixed methods research employs different approaches, it enhances the trustworthiness of the study (Guest 2012). A sequential exploratory design was adopted to collect and analyse qualitative data first, which was followed by the collection and analysis of quantitative data (Creswell 2007). This design was used mainly to differentiate the groupings and develop taxonomies for use in the TABS instrument. The intent was to validate the instrument in order to identify the attitudes of Omani students and native speakers of Arabic towards technology. Also, the aim was to determine whether the qualitative topics could be widespread in Arab college students.

The principle underlying the sequential exploratory mixed methods design is the development of an assessment instrument that does not yet exist (Creswell 2007). The absence of an assessment to determine Arab students' attitudes towards technology contributed towards the selection of the sequential exploratory mixed methods design. A common factor of the sequential exploratory mixed methods design is that both the qualitative and quantitative approaches help in the development of a quantitative instrument. The incorporation of a qualitative method aided in the production of data. This complementary section focused primarily on the role that the panel of experts played during the adaptation and translation of the ABS, which was crucial in the validation phase. The panel of experts' knowledge of both languages and the Arab culture helped in deciphering linguistic and cultural meanings in the translated version of the ABS. Their actions averted misunderstandings of the items contained in the quantitative section of the TABS. The application of this procedure offered vital data about the TABS, i.e. it interrogated the purpose of the TABS and assessed whether the cultural and linguistic potential misunderstandings were effectively attended in the validation adaptation phase.

\section{Designing the TABS instrument}

The process of designing the TABS started with finding an instrument that could measure technological attitudes. The PATT-USA (Bame et al. 1993) was the perfect instrument to use as a principal model in the design of the TABS. The initial translation of the ABS from English to Arabic served as a basis to start the adaptation validation phase of this study. The TABS consists of 6 subscales. Subscales 1-5 are identical to the PATT- USA. The sixth subscale is about language choice. In total, the TABS consists of 68 items (see Annexure 1). The first item is part of the qualitative section of the study. This item requires the participants to write a brief description of what they think technology is. The next five items identify the participants' gender, age, English language level (classified by college), major and location of college. The next section includes 58 items about attitudes towards technology and four items about language choice to establish a baseline from a sociolinguistic perspective, that is, to discover language attitudes towards learning and using technology in a second language.

Currently, the lingua franca is English. Technology as well as most information in cyber space is in English (Jarvis 2005). In the Middle East, particularly in the Gulf States English is used as a medium of instruction in colleges and universities (Al-Issa 2005; Al-Jarf 2008; Troudi 2002; Findlow 2006). 
The Language Choice subscale (LCs) is included to investigate an attitude in relation to the two languages used in the TABS. Specifically, the LCs intended to assess the participants' viewpoint on being forced to attain a college degree in a foreign language (English) instead of their native language (Arabic). What is the message that the participants are getting when in their own land Arabic is no longer a vehicle to obtain a college degree? The LCs forces the participants to evaluate which of both languages is best for them in technology and their education. The addition of the Language Choice (LC) subscale is a noteworthy difference between the TABS and the PATT-USA. Overall, the TABS instrument includes the subscales shown in Table 2.

The function of the Language Choice (LC) subscale is to assess Omani students' attitudes towards the English and Arabic languages. Al-Issa (2006) reasons that Omani tertiary institutions' adoption of English as a medium of instruction and curricula is intrusive. The status of the English language is elevated in colleges and universities, while the Arabic language is demoted. This linguistic situation in Oman enriches the position of both languages. Whether this enrichment is positive or negative, the LC subscale could contribute to the perception of Omanis' language attitudes.

The items (6-67) about assessing the attitudes in technology and language were arranged in a Likert scale format. The Likert scale, in the case of the TABS, is divided into five choices where the participants had to stipulate their degree of agreement with the items contained in the questionnaire. The choices are given in Table 3.

\section{Data collection procedures}

The inclusion of both the qualitative and quantitative data collection procedures reflected the nature of the mixed methods approach to this study. The character of the TABS dictated to apply a purposive sampling technique. The need to select particular individuals to critique the TABS dictated that a purposive sampling technique be used, because these individuals belonged to a particular group of competent professionals. The application of purposive sampling techniques necessitated the participation of persons who possess knowledge in specific fields for exceptional tasks (Cohen et al. 2005). Firstly, an invitation letter was sent to several panelists requesting their participation in this study. In selecting this panel, two factors were considered, i.e. the participant's availability and his/her willingness to cooperate in the study. In the end, a panel of experts was constituted, consisting of four experts who would evaluate the TABS. These experts were approachable and keen to participate in the study. They were teachers and researchers at a small four-year college in Oman. They were native speakers of Arabic. Their research-writing experience was in English and Arabic. Table 4 shows a brief description of the expert panel members who participated in the study.

The participation of these experts was an important factor in the adaptation validation phase of the study. Their task was to assess the translated instrument and suggest changes, ideas and highlight problems, whether linguistic or cultural, to generate a linguistic and cultural bias-free instrument. Their final task during the adaptation validation phase was to determine the content validity (trustworthiness) of the instrument. The first researcher in this article met with them and explained their role in the validation of the instrument. The specific guidelines given to the panel of experts on how to evaluate the TABS were explained as follows: 


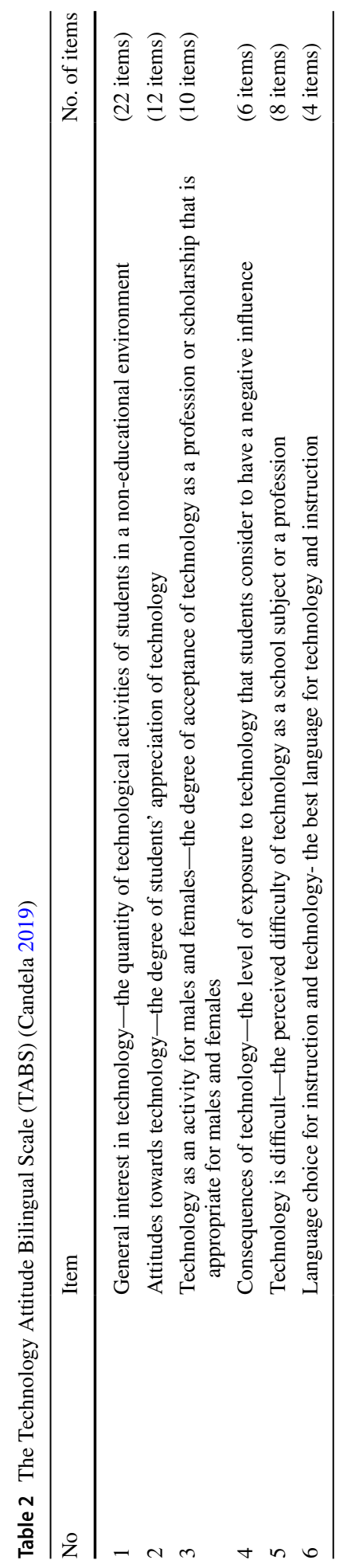


Table 3 Likert Scale choices (Candela 2019)

\begin{tabular}{|c|c|c|c|c|}
\hline 1 & 2 & 3 & 4 & 5 \\
\hline $\begin{array}{c}\text { Strongly disagree } \\
\text { لا أوافق بشدة }\end{array}$ & $\begin{array}{l}\text { Disagree } \\
\text { لا أوافق }\end{array}$ & $\begin{array}{l}\text { Neutral } \\
\text { محايد }\end{array}$ & $\begin{array}{l}\text { Agree } \\
\text { أوافق }\end{array}$ & $\begin{array}{c}\text { Strongly agree } \\
\text { أوافق بشدة }\end{array}$ \\
\hline
\end{tabular}

Table 4 Description of the panel of experts

\begin{tabular}{|c|c|c|c|c|c|}
\hline Nationality & Gender & Languages & Areas of expertise & Qualification & Experience \\
\hline 1. Syrian & Male & English and Arabic & $\begin{array}{l}\text { English/Arabic trans- } \\
\text { lation } \\
\text { Applied linguistics } \\
\text { Technology }\end{array}$ & Doctorate & $\begin{array}{l}\text { UN translator } \\
\text { English teaching } \\
\text { Arabic culture }\end{array}$ \\
\hline 2. Sudanese & Female & English and Arabic & $\begin{array}{l}\text { Research methods } \\
\text { Education } \\
\text { Technology }\end{array}$ & Doctorate & $\begin{array}{l}\text { Researcher } \\
\text { Translator } \\
\text { Arab culture }\end{array}$ \\
\hline 3. Omani & Female & English and Arabic & $\begin{array}{l}\text { Arabic language } \\
\text { Arabic teaching } \\
\text { Omani culture }\end{array}$ & Doctorate & $\begin{array}{l}\text { Researcher in Arabic } \\
\text { Research Unit Director }\end{array}$ \\
\hline 4. Sudanese & Male & English and Arabic & $\begin{array}{l}\text { English/Arabic trans- } \\
\text { lation } \\
\text { Arabic teaching } \\
\text { English teaching }\end{array}$ & $\begin{array}{l}\text { MA in } \\
\text { Applied } \\
\text { Linguistics }\end{array}$ & $\begin{array}{l}\text { Teaching } \\
\text { Research } \\
\text { Translation }\end{array}$ \\
\hline
\end{tabular}

- Based on your linguistic knowledge of the Arabic and English languages, judge the statements in both languages and see if there are any misunderstandings that might have filtered during the translation. If any, provide an alternative that you think best represents the idea portrayed in the item or items in question.

- Based on your cultural knowledge of the Arab world, judge the statements in both Arabic and English languages and see if there are any misunderstandings that might insult or could be considered as insensitive to the Arab culture. If any, provide a reason for your conclusion and an alternative that you think best represents the idea portrayed in the item or items in question.

The adaptation validation version of the TABS was hand-delivered by the researcher to the panel of experts at the above identified college in Oman and the modifications were completed thereafter.

Firstly, the panel of experts received a pilot bilingual version \#1 of the TABS. Version 1 was administrated to the participants (not reported in any of the three phases of this investigation) prior to the involvement of the panel of experts. Next, the panel of experts worked independently on Version 1. During this process, the first researcher in this article, due to his knowledge of the culture and language as an Omani, played a leading role in the evaluation of all the panel members. He concluded that expert 1 was the most experienced in the art of translation based on his professional experience. This researcher arrived at this conclusion after carefully reviewing expert 1 's experience and a number of face-to-face conversations in English and Arabic. Consequently, experts 1, 2, 3 and 4 had an opportunity to review version 1 and produced Version 2. Subsequently, expert 1 gathered Version 2 of the TABS supplied by experts 2,3 and 4 .

While this review took place, the panel of experts met and discussed some of the items. One example was item 38 which reads in English "I should be able to take technology as a 
school subject". In Arabic, it was personalised, it reads: "I should be able to take technology as a school subject at my college". This was done with the idea of keeping the originality of the PATT in English. Other examples of these modifications were the name of the instrument, that it is from Technology Attitude Scale (TAS) to TABS, addition of a sentence stating that the TABS was being used for research purposes, text corrections in Arabic, etc. Modifications, additions and deletions were discussed and agreed upon amongst the experts. All changes are reported in Annexure 2.

\section{Results}

The panel of experts were instrumental in perfecting the English to Arabic translation of the TABS. Independently from the translation, the panel of experts' tasks involved criticising and suggesting any modifications during the adaptation validation version of the TABS phase 1.

\section{Suggested changes in the TABS by the panel of experts}

The panel of experts determined the trustworthiness of the TABS-Arabic/English. The fact that the experts were competent bilinguals meant that their recommendations concerning the accuracy of the translation of the questionnaire from English into Arabic were vital. The entire set of recommendations about the integration of Arabic and English into the TABS was adopted. However, structural recommendations about the instrument were not respected. The need to adhere to the originality of the PATT dictated that the researchers ignore structural suggestions. The panel focused on language clarity. They suggested important modifications in the language of translation. Their recommendations were in areas such as the title of the instrument, instructions, participants' personal information, an open-ended question and the correction of 38 out of 61 statements. For instance, Q\#50: Original statement, "English should be taken by all pupils" was corrected to read: "English should be taken by all students" in the final Arabic version of the TABS. Table 5 shows the items that were modified from the adaptation validation phase to the final version of the TABS-Arabic/English (for individual item corrections, see Annexure 2).

After reviewing the adaptation validation Phase 1 version of the instrument, Expert 2 suggested that the layout of the items should be changed. Expert 2 judged that, according to her long teaching experience at college level, the order of the items could confound the participants. Specifically, Expert 2 suggested the following:

1. "The items need to be reorganised."

2. "The organisation is not clear, students will be jumping back and forth."

3. "The statements must be arranged by topics."

4. "A cover letter should be sent to all participants."

5. "What is the relationship connecting the last four statements of the questionnaire?"

The need to adhere to the original PATT instrument suggested the disregard for the first, second and third statements in the above advice. The fourth point of advice was incorporated into the procedural format of the study. The last point of advice was addressed and discussed with Expert 2. The explanation was that the LC subscale assessed the attitude of Arabic and English in two areas. The first area related to the role of English or Arabic as 


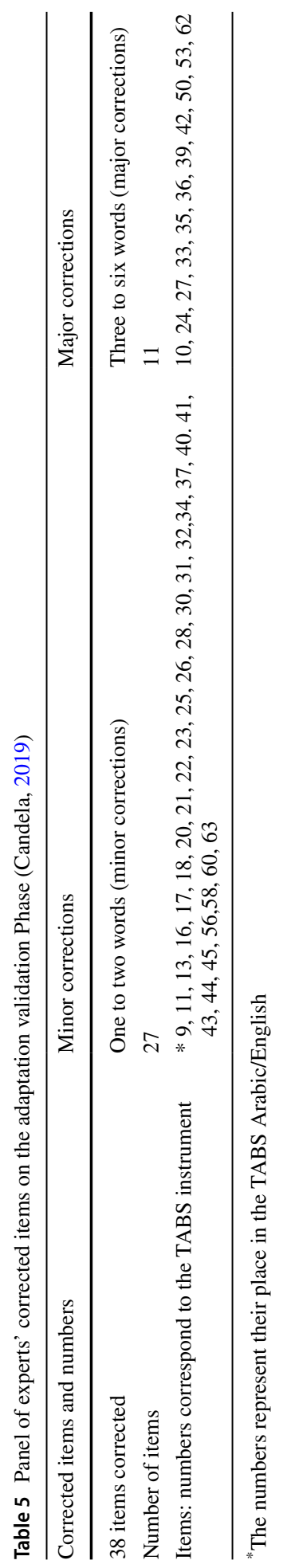


a medium of instruction in Oman and consequently in the Middle East. The second area assessed which language the participants felt was the perfect language to deal with, use, apply and execute technology. Expert 1, as the most experienced translator, saw that the TABS was a linguistically sound translated instrument (corrections shown in Annexure 2). The advice offered by Expert 1 was added to the TABS-Arabic/English. The TABS was also reviewed by Expert 3, a specialist in Arabic, who, after a thorough review of the instrument, commented that the TABS Arabic/English was, in her professional opinion, linguistically and culturally error-free. Expert 3 unequivocally agreed with the corrections and suggestions offered by Expert 1. In addition, Expert 3 suggested that a sentence should be added, stating that the TABS was designed for research purposes. Expert 3's suggestion was incorporated into the final version of the TABS-Arabic/English. Expert 4 suggested that the instructions should be clearer. These changes were incorporated in the final version of the instrument.

The involvement of the panel of experts portrayed above was vital in establishing the validity for the TABS-Arabic/English. The newly revised version of the instrument was used in the adaptation validation Phase 2. (See Annexure 2 for all the corrections.)

\section{Discussion and recommendations}

The TABS is a bilingual instrument that measures technology attitudes of college-age students who are Arabic native speakers and study in an English-medium environment.

The validation of the TABS instrument is conducted in three phases: Phase 1 involves the adaptation/translation and the structuring of the TABS. This phase involves a panel of experts to revise and then create an instrument to measure technology attitudes of the native speakers of Arabic who are studying Technology Education. Phase 2 is the administration of the TABS instrument to the Technology instructors teaching Engineering courses in both languages at a technology college. Phase 2 concentrates on the Arabic content of the items in the TABS. The work of the Technology instructors is to evaluate the task performed by the panel of experts and provide any modifications, additions and deletions and supply suggestions in changing the items in the TABS to remove any ambiguities. Phase 3 , the final phase in the validation process of the TABS, is about the administration of the TABS to a large group of Engineering students at a technology college. The narrative section is analysed by using a technique called "coding" and the items are statistically analysed using SPSS (a program to validate the TABS by using statistical measurements). Phase one is the scope of this article.

The Middle East has adopted English as the language of instruction at their institutions of higher learning (Al-Issa 2005; Al-Jarf 2008; Troudi 2002); thus the bilingual TABS. The items in the TABS were inspected in the original language to identify any cultural differences. Subsequently, the items were adjusted to conform linguistically to the Arabic language and culture for Arabs. Overall, the TABS was adapted to complement Omani college students. The bilingual format of the TABS was aimed at the nullification of language interference and the eradication of the language comprehension variables in the native speakers of Arabic. This gives positive credence to the data collected using a bilingual instrument. In general, the TABS could help with the design and implementation of technology-oriented programmes in all educational areas. The TABS presents some positive points, which are: 
- It is easy to administer.

- It creates a sense of accomplishment because it is a reliable instrument that can yield immediate results.

- Analyses can be conducted rapidly.

- Findings can be recorded and interpreted to accommodate the college's aims and inform the administrators.

A negative point regarding the TABS is that it is too long. Perhaps a shorter version could be incorporated further into the continuum development of the TABS. A significant difference between the PATT-USA and the TABS is the inclusion of the Language Choice (LC) subscale. The LC subscale addresses the bilingual situation in colleges and universities in the Middle East. The LC subscale aims to discover language attitudes in technology and instruction. The principal conclusion of this investigation is that the TABS is a sound and trustworthy instrument.

The adaptation and translation of the ABS from the original PATT-USA (Bame et al. 1993) to the appropriate language clarity and brevity for administration to college students was accomplished. Furthermore, the following recommendations pertaining to the TABS are offered:

- The results of this study could serve as a foundation to propose additional objectives for consideration in future research.

- An improved TABS could help in the acceptance of a higher alpha level for all scales.

- The forthcoming TABS research could include several colleges in Oman, thus, a large number of participants.

- TABS versions for middle-school students could be developed.

- A TABS manual could be developed for the Arab teachers at all levels.

- The prominent segregation of males and females in an Omani setting could be the reason for addressing the construct of gender in technology attitudes.

The statement above is based on a socio-cultural tradition in the Arab culture. In which women and men have their own stations. The clearest example is item 18 in the TABS which states, "A girl can become a car mechanic." This mere statement goes against their cultural values; nevertheless, it can elicit an answer. Males would probably answer negatively and perhaps some bold females would answer positively. The next step is to analyse males' and females' answers to this statement. It is not within the scope of this article to perform such task. However, Svenningsson et al. (2018) provide the perfect avenue to embark on an investigation to reveal gender-specific attitudes towards technology by replicating their study. In sum, Svenningsson et al (2018) suggest to use the third version of the survey which includes the Gender M and Gender F. According to Dakers et al. (2009), because of cultural restrictions, Omani society still wrestles with gender-specific matters in technology education.

- The TABS and the original PATT instrument lend themselves to mixed methods approaches; therefore, an appeal is made to emphasise a mixed methods research design.

- Previous PATT studies that did not provide the numerical data required to perform statistical analysis should be re-issued and disseminated.

- A longitudinal study using the TABS is needed.

- Technology lecturers should use the TABS to learn about their students. 
The TABS could be used in research projects dealing with Technology Education. Hence, the following recommendations for further research are made:

- Although the TABS was adapted to be used with college-age students, the TABS can be adapted to investigate whether or not teachers and lecturers know the difference between Technology Education and Educational Technology in an Omani context. Gumbo (2018) addresses this issue in Technology Education.

- The technology attitudes of college instructors teaching academic and Technology subjects could be investigated.

- TABS research should continue to serve as a platform to address issues in technology and provide valuable contribution in promoting Technology Education.

- TABS should stimulate large-scale cross-cultural research to compare technology attitudes across the Arabic speaking world.

Technology Education as a relative new field of study (Gumbo 2013) on a global scale, particularly in the Omani context, needs to be addressed and the TABS could play a role in this matter. In brief, the following recommendations are proposed that would benefit the field of Technology Education:

- Educators and technologists involved in teacher education should use innovative ways to develop technology activities and programmes to improve college students' attitudes towards technology.

- Technology Education should be introduced at an early age in students' education.

- A broad concept of technology should be introduced in Technology Education to address different areas of technology.

- The Omani national curriculum needs to include Technology Education.

- Boundaries should be clear in order to connect Technology Education as a main element in the area of technology in general and to include colleges and universities to create a technologically literate population.

- The changes in Technology Education should come from within Omani society. Guidance should come in the form of Technology Education practitioners from other places where Technology Education is already cemented.

The notion that Omani society is a developing technological society and is willing to participate in the process of globalisation should provide the motivational bases to invest in Technology Education.

\section{Conclusion}

The content validity (trustworthiness) of the TABS was determined by the panel of experts. They inspected the subject matter of the TABS and recommended relevant avenues to adapt and modify items in the instrument. They resolved that the items were pertinent to ascertain attitudes towards technology for engineering students in both Arabic and English. It was resolved with assistance and suggestions from the panel of experts that the revised TABS-Arabic/English instrument could possibly be effectively administrated to participants in Phases 2 and 3. Furthermore, the panel of experts concluded that the TABS instrument had substantial content validity. 


\section{Annexure 1: TABS final version (Candela 2019)}

Technology Attitude Bilingual Scale (TABS-Arabic/English) adapted from PATT-USA (Bame et al. 1993)

$$
\text { استطلاع آراء الطلاب في استخدام التكنولوجيا }
$$

\section{Instructions to participants (Engineering students):}

1. If you see a word in Arabic that you do not understand, please underline it.

2. If you read a sentence in Arabic and you do not understand, please underline it.

3. If you have any comments, please write them below.

4. By completing the questionnaire, you grant permission to the researcher to use your answers for research purposes.

التعليمات للمشاركة الصفية:

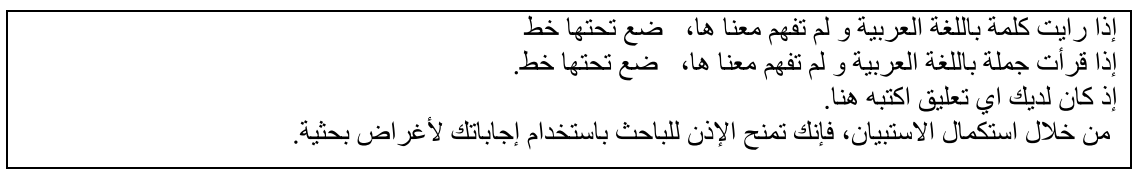

\section{Technology Attitude Bilingual Scale (TABS-Arabic/English) adapted from PATT-USA (Bame et al., 1993) \\ استطلاع آراء الطلاب في استخدام التكنولوجياثنائيةاللغة}

Instructions: Please answer all the questions. This questionnaire is about technology. It is not a test. Your answers will be used for research only.

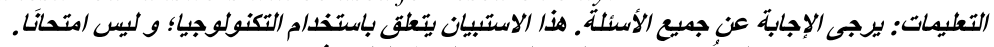

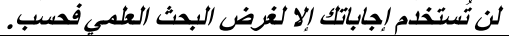

Please write a short description of what you think technology is: Please write it in English or Arabic. Your choice.

يرجى كتابة وصف موجز لما تعتق أنه معنى التكنولوجيا. لك الخيار في الكتابة بإحدى اللغتين: العربية أو الإنجليزية.

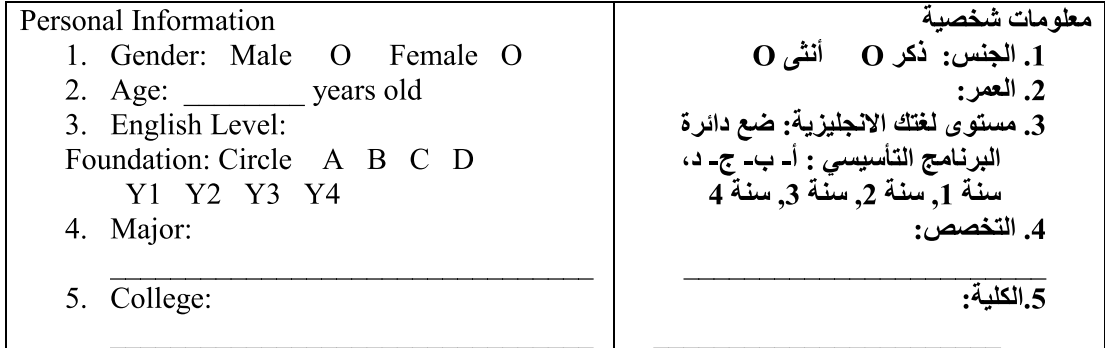


1

Strongly

disagree

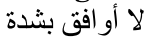

\section{2}

Disagree

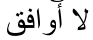

3

Neutral

محايد
4

Agree

أو افق
5

Strongly agree

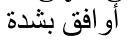

6. When something new is discovered I want to know more $\begin{array}{llllll}1 & 2 & 3 & 4 & 5\end{array}$ about it immediately.

عندما ينم اكتشاف شيء جديد أود معرفة المزيد عنه فوراً.

7. Technology is as difficult for boys as it is for girls.

يواجه الفتيان و الفتيات نفس الصعوبة عند استخدام التكنولوجيا.

8. Technology is good for the future of this country.

التكنولوجيا جيدة لمستقبل هذا البلد.

9. To understand something of technology you have to take a $\begin{array}{llllll}1 & 2 & 3 & 4 & 5\end{array}$ difficult training course.

لفهم شيء ما في التكنولوجيا عليك أن تخضن لبرنامج تدريبي صعب.

10. At school you hear a lot about technology.

تسمع كثير ا عن استخدام التكنولوجيا في المدرسة.

11. I will probably choose a job in technology.

على الأرجح سأختار وظيفة في استخدام التكنولوجيا.

12. I could like to know more about computers.

أود معرفة المزيد عن الحواسيب.

13. A girl can very well have a technological job.

يمكن للفتاة أن تحصل على وظيفة في استخدام التكنولوجيا.

14. Technology makes everything work better. تجعل التكنولوجيا كل شيء يعمل بشكل أفضل.

15. You have to be smart to study technology.

يجب أن تكون ذكياً لتدرس التكنولوجيا.

16. I could like not to learn more about technology at school. $\begin{array}{llllll}1 & 2 & 3 & 4 & 5\end{array}$ لا أود أن أتعلم المزيد عن استخدام التكنولوجيا في المدرسة.

17. I like to read technological magazines. أحب أن أقر أ المجلات التي تتناول مجال التكنولوجيا.

18. A girl can become a car mechanic. يمكن للفتاة أن تصبح ميكانيكية لإصلاح السيارات.

19. Technology is very important in life. التكنولوجيا مهمة جداً في الحياة.

20. Technology is only for smart people. التكنولوجيا للأذكياء فقط. 
21. Technology lessons are important.

الدروس التكنولوجية مهية.

22. I will not consider a job in technology.

لن أتقدم لوظيفة في مجال التكنولوجيا.

23. There should be less TV and radio programs about $\begin{array}{llllll}1 & 2 & 3 & 4 & 5\end{array}$ technology.

ينبغي التقليل من البر امج المتعلقة باستخدام التكنولوجيا على التلفاز و الراديو.

24. Boys are able to do practical things better than girls.

يستطيع الفتيان القيام بأثياء عملية أفضل من الفتيات.

25. Everyone needs technology.

يحتاج جميع الناس إلى التكنولوجيا.

26. I could rather not have technology lessons in school.

من الأفضل أن لا أدرس عن التكنولوجيا في المدرسة.

27. I do not understand why anybody could want a job in $\begin{array}{llllll}1 & 2 & 3 & 4 & 5\end{array}$ technology.

لا أستطيع فهم اختيار أحدهم وظيفة تتضدن استخدام التكنولوجيا.

28. If there was a college club about technology I could $\begin{array}{llllll}1 & 2 & 3 & 4 & 5\end{array}$ certainly join it.

لو كان هنالك نادي أو جماعة طلابية في كليتي عن استخدام التكنولوجيا فإنني

حتما سألتحق بها.

29. Girls are able to operate a computer.

تسنطيع الفتيات تشغيل الحاسوب.

30. Technology has brought more good things than bad.

جلبت التكنولوجيا أمورا إيجابية أكثر من السلبية.

31. You have to be strong for most technological jobs.

يجب أن تكون قوياً في معظم المهن التي تتعلق بمجال التكنولوجيا.

32. Technology at home is something schools should teach $\begin{array}{llllll}1 & 2 & 3 & 4 & 5\end{array}$ about.

ينبغي تدريس التكنولوجيا المنزلية في المدارس.

33. I could enjoy job in technology.

أعتقد أنني سأستمتع بشغل وظيفة في مجال التكنولوجيا.

34. I think visiting a factory is boring.

أظن أن زيارة المصنع مملة.

35. Boys know more about technology than girls do.

القتيان أكثر إلماماً بالتكنولوجيا من الفتيات.

36. The world could be a better place without technology. سيكون العالم مكانا أفضل بدون استخدام التكنولوجيا.

37. To study technology you have to be talented.

لابد أن تكون موهوباً لتدرس التكنولوجيا. 
38. I should be able to take technology as a school subject. ينبغي أن يكون بإمكاني دراسة مادة التكنولوجيا كأحد المقررات التعليمية في كليتي.

39. I could like a career in technology later on.

سأختار وظيفة في مجال التكنولوجيا لاحقاً.

40. I am not interested in technology.

أنا غير مهتم باستخدام التكنولوجيا.

41. Boys are more capable of doing technological jobs than $\begin{array}{llllll}1 & 2 & 3 & 4 & 5\end{array}$ girls.

الفتيان أكثر قدرة على شغل وظائف في استخدام التكنولوجيا من الفتيات.

42. Using technology makes a country less prosperous.

أستخدام التكنولوجيا يجعل البلد أقل ازدهار ا.

$\begin{array}{lllllll}\text { 43. You can study technology only when you are good in both } & 1 & 2 & 3 & 4 & 5\end{array}$ mathematics and science.

تسنطيع در اسة التكنولوجيا فقط عندما تكون جيداً في الرياضيات و العلوم.

44. There should be more education about technology.

ينبغي أن يكون هناك تعليم أكثر عن استخدام التكنولوجيا.

45. Working in technology could be boring.

العمل في حقل استخدام التكنولوجيا ممل.

46. I enjoy repairing things at home.

أستمتع بتصليح الأشياء بالمنزل.

47. More girls should work in technology.

ينبغي زيادة عدد الفتيات العاملات في قطاع التكنولوجيا.

48. Technology causes large unemployment.

$$
\text { يؤدي استخدام التكنولوجيا إلى زيادة البطالة. }
$$

49. Technology does not need a lot of mathematics.

$$
\text { لا تحتاج استخدام التكنولوجيا إلى الكثير من الرياضيات. }
$$

50. Technology as a subject should be taken by all pupils.

$$
\text { ينبغي على جميع التلاميذ در اسة التكنولوجيا كمادة تعليمية. }
$$

51. Most jobs in technology are boring.

أغلب الوظائف في قطاع التكنولوجيا مملة.

52. I think machines are boring.

$$
\text { أعثقد أن الآلات مملة. }
$$

53. Girls prefer not to go to a technical school.

تفضل الفتيات عدم الذهاب إلى كلية تدِّرس التكنولوجيا.

$\begin{array}{lllll}1 & 2 & 3 & 4 & 5 \\ 1 & 2 & 3 & 4 & 5 \\ 1 & 2 & 3 & 4 & 5 \\ 1 & 2 & 3 & 4 & 5 \\ 1 & 2 & 3 & 4 & 5 \\ 1 & 2 & 3 & 4 & 5\end{array}$

54. Because technology causes pollution, we should use less of it.

ينبغي أن نقلل من استخدام التكنولوجيا لأنها تسبب التلوث. 
55. Everybody can study technology.

يستطيع جميع الناس دراسة التكنولوجيا.

56. Technology lessons help you train for a good job. الدروس التكنولوجية قد تساعدك في الإعداد لوظيفةٍ جيدةٍ.

57. Working in technology could be interesting.

سيكون العمل في قطاع التكنولوجيا ممتعاً.

58. A technological hobby is boring. الهواية التكنولوجية مملة.

59. Girls think technology is boring.

تعتقد الفتيات أن التكنولوجيا مملة.

60. Technology is the subject of the future.

التكنولوجيا مادة/علم المستقبل.

61. Everybody can have a technological job.

يستطيع جميع الناس الحصول على وظيفة في قطاع التكنولوجيا.

62. Not everyone needs technology lessons at school.

ليس كل شخص يحتاج لدروس في استخدام التكنولوجيا في المدرسة.

63. With a technological job your future is promised. سيكون مستقبلك و اعداً بحصوللك على وظيفة في مجال التكنولوجيا.

64. English is not the best language for technology. اللغة الإنجليزية هي ليست اللغة الأنسب للتكنولوجيا.

65. Arabic is the best language for technology. اللغة الأنسب للتكنولوجيا. اللغة العربية هي

$\begin{array}{lllll}1 & 2 & 3 & 4 & 5\end{array}$

$\begin{array}{lllll}1 & 2 & 3 & 4 & 5\end{array}$

$\begin{array}{lllll}1 & 2 & 3 & 4 & 5\end{array}$

$\begin{array}{lllll}1 & 2 & 3 & 4 & 5\end{array}$

$\begin{array}{lllll}1 & 2 & 3 & 4 & 5\end{array}$

$\begin{array}{lllll}1 & 2 & 3 & 4 & 5\end{array}$

$\begin{array}{lllll}1 & 2 & 3 & 4 & 5\end{array}$

$\begin{array}{lllll}1 & 2 & 3 & 4 & 5\end{array}$

$\begin{array}{lllll}1 & 2 & 3 & 4 & 5\end{array}$

$\begin{array}{lllll}1 & 2 & 3 & 4 & 5\end{array}$

$\begin{array}{lllll}1 & 2 & 3 & 4 & 5\end{array}$

$\begin{array}{lllllll}66 . & \text { English should not be the language of instruction in my } & 1 & 2 & 3 & 4 & 5\end{array}$ college.

لا ينبغي أن تكون اللغة الإنجليزية هي لغة التعليم في كليتي.

$\begin{array}{llllll}\text { 67. Arabic should be the language of instruction in my college. } & 1 & 2 & 3 & 4 & 5\end{array}$ ينبغي أن تكون اللغة العربية هي لغة التعليم في كليتي.

\section{Annexure 2: Panel of experts' item corrections (Candela 2019)}

[30 items corrected: 1 to 2 words (*27 minor corrections); 3 to 6 words (+11 major corrections)]. 


\begin{tabular}{|c|c|c|}
\hline $\begin{array}{c}\text { Item } \\
\text { no. }\end{array}$ & Pre-panel of experts & After panel of experts \\
\hline $9^{*}$ & 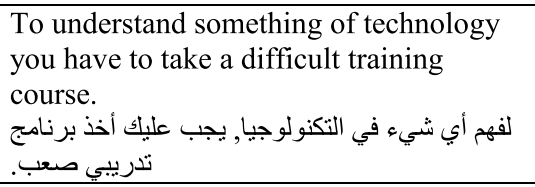 & $\begin{array}{l}\text { To understand something of technology } \\
\text { you have to take a difficult training } \\
\text { course. } \\
\text { لفهم شيء ما في التكنولوجيا عليك أن تخريخ لبرنامب صبع }\end{array}$ \\
\hline $10+$ & $\begin{array}{l}\text { At school you hear a lot about } \\
\text { technology. } \\
\text { في المدرسة تسمع كثير عن التكنولوجيا. }\end{array}$ & $\begin{array}{l}\text { At school you hear a lot about } \\
\text { technology. } \\
\text { تسمع كثير ا عن استخدام التكنولوجيا في المدرسة. }\end{array}$ \\
\hline $11^{*}$ & 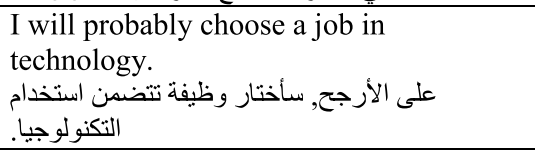 & $\begin{array}{l}\text { I will probably choose a job in } \\
\text { technology. } \\
\text { على الأرجح سأختار وظيفة في استخدام التكنولوجيا. }\end{array}$ \\
\hline $13^{*}$ & $\begin{array}{l}\text { A girl can very well have a technological } \\
\text { job. } \\
\text { يمكن للفتاة أن تحصل على وظيفة نتضمن استخدام التكنوجيا. }\end{array}$ & $\begin{array}{l}\text { A girl can very well have a technological } \\
\text { job. } \\
\text { يمكن للفتاة أن تحصل على وظيفة في استخدام التكنوجيا. }\end{array}$ \\
\hline $16^{*}$ & $\begin{array}{l}\text { I could like not to learn more about } \\
\text { technology at school. } \\
\text { لا أود نعلم التكنولوجيا في المدرسة. }\end{array}$ & $\begin{array}{l}\text { I could like not to learn more about } \\
\text { technology at school. } \\
\text { لأود أن أتعلم المزيد عن استخدام التوجيا في المدرسة. }\end{array}$ \\
\hline $17^{*}$ & $\begin{array}{l}\text { I like to read technological magazines. } \\
\text { أحب أن أقرأ الدجلات التي تتحدث عن التكوليا. }\end{array}$ & 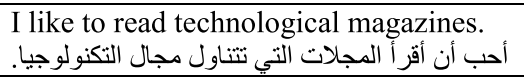 \\
\hline $18^{*}$ & $\begin{array}{l}\text { A girl can become a car mechanic. } \\
\text { يمكن للفتاة أن تصبح ميكانيكية سيارات. }\end{array}$ & $\begin{array}{l}\text { A girl can become a car mechanic. } \\
\text { يمكن للفتاة أن تصبح ميكانيكية لإصلاح السيارات }\end{array}$ \\
\hline $20 *$ & $\begin{array}{l}\text { Technology is only for smart people. } \\
\text { التكنولوجيا للناس الأكباء وحسب. }\end{array}$ & $\begin{array}{l}\text { Technology is only for smart people. } \\
\text { التكنولوجيا للأذكياء فقط. }\end{array}$ \\
\hline $21^{*}$ & $\begin{array}{l}\text { Technology lessons are important. } \\
\text { دروس التكنولوجيا مهمة. }\end{array}$ & $\begin{array}{l}\text { Technology lessons are important. } \\
\text { الدروس التكنولوجية مهمة. }\end{array}$ \\
\hline $22 *$ & $\begin{array}{l}\text { I will not consider a job in technology. } \\
\text { لن أتقدم لوظيفة تتضمن استخدام التكنوجيا. }\end{array}$ & $\begin{array}{l}\text { I will not consider a job in technology. } \\
\text { لن أتقدم لوظيفة في مجال التكنولوجيا. }\end{array}$ \\
\hline $23^{*}$ & 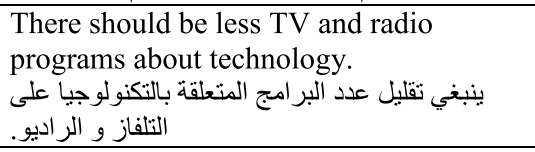 & 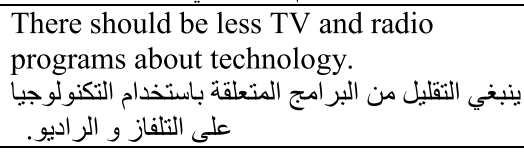 \\
\hline $24+$ & $\begin{array}{l}\text { Boys are able to do practical things better } \\
\text { than girls. } \\
\text { يسنطيع الفتيان القيام بأشياء عملية أفضل من الفتيات. }\end{array}$ & $\begin{array}{l}\text { Boys are able to do practical things better } \\
\text { than girls. } \\
\text { يسنطيع الفتيان القيام بأشياء عملية أفضل من الفتيات. }\end{array}$ \\
\hline $25^{*}$ & $\begin{array}{l}\text { Everyone needs technology. } \\
\text { يحتاج جميع الناس إلى التكنولوجيا. }\end{array}$ & $\begin{array}{l}\text { Everyone needs technology. } \\
\text { يحتاج جميع الناس إلى التكنولوجيا. }\end{array}$ \\
\hline
\end{tabular}




\begin{tabular}{|c|c|c|}
\hline $\begin{array}{c}\text { Item } \\
\text { no. }\end{array}$ & Pre-panel of experts & After panel of experts \\
\hline $26^{*}$ & $\begin{array}{l}\text { I could rather not have technology } \\
\text { lessons in school. } \\
\text { أفضل أن لا أحصل على دروس التكنوليا في. المدرسة. }\end{array}$ & $\begin{array}{l}\text { I could rather not have technology } \\
\text { lessons in school. } \\
\text { من الأفضل أن لا أدرس عن التكنوجيا في المدرسة. }\end{array}$ \\
\hline $27+$ & 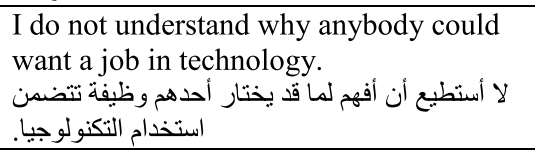 & 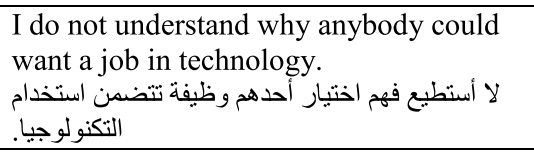 \\
\hline $28^{*}$ & 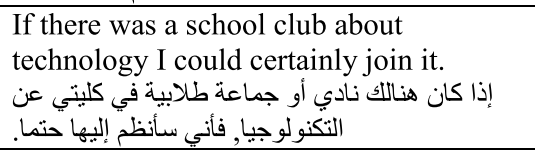 & 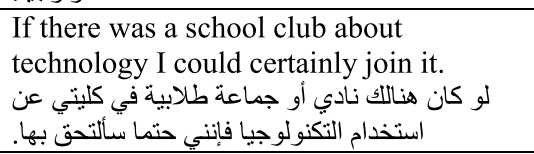 \\
\hline $30^{*}$ & $\begin{array}{l}\text { Technology has brought more good } \\
\text { things than bad. } \\
\text { جلبت التكنولوجيا أثشياء إيجابية أكثر من الأشياء. }\end{array}$ & $\begin{array}{l}\text { Technology has brought more good } \\
\text { things than bad. }\end{array}$ \\
\hline $31 *$ & 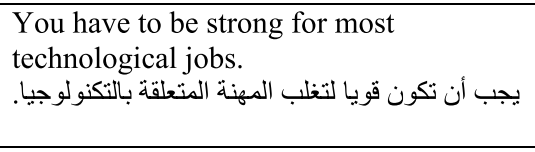 & 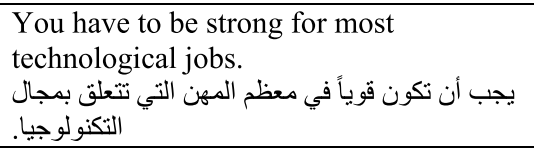 \\
\hline $32 *$ & $\begin{array}{l}\text { Technology at home is something schools } \\
\text { should teach about. } \\
\text { ينبغي تدريس التكنولوجيا المنزلية في المدارس. }\end{array}$ & $\begin{array}{l}\text { Technology at home is something schools } \\
\text { should teach about. } \\
\text { ينبغي تدريس التكنولوجيا المنزلية في المدارس. }\end{array}$ \\
\hline $33+$ & $\begin{array}{l}\text { I could enjoy job in technology. } \\
\text { أعتقد أني سأستمتع بشغل وظيفة في قطاع التكنولوجيا. }\end{array}$ & $\begin{array}{l}\text { I could enjoy job in technology. } \\
\text { أعقد أنني سأستمتع بشغل وظيفة في مجال التكوجيا. }\end{array}$ \\
\hline $34^{*}$ & $\begin{array}{l}\text { 1. I think visiting a factory is boring. } \\
\text { أظن زيارة المصنع مملة. }\end{array}$ & $\begin{array}{l}\text { I think visiting a factory is boring. } \\
\text { أظن أن زيارة المصنع مملة. }\end{array}$ \\
\hline $35+$ & $\begin{array}{l}\text { Boys know more about technology than } \\
\text { girls do. } \\
\text { الفتيان أكثر ألماما بالتكنولوجيا من الفتيات }\end{array}$ & $\begin{array}{l}\text { Boys know more about technology than } \\
\text { girls do. } \\
\text { الفتيان أكثر إلماماً بالتكنولوجيا من الفتيات. }\end{array}$ \\
\hline $36+$ & $\begin{array}{l}\text { The world could be a better place without } \\
\text { technology. } \\
\text { سيكون العالم مكانا أفضل بدون استخدام التكنولوجيا. }\end{array}$ & $\begin{array}{l}\text { The world could be a better place without } \\
\text { technology. } \\
\text { سيكون العالم مكانا أفضل بدون استخدام التكنولوجيا. }\end{array}$ \\
\hline $37^{*}$ & 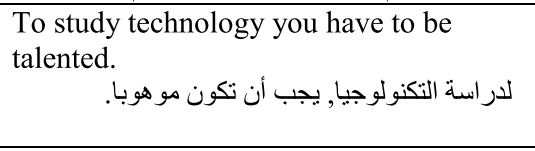 & $\begin{array}{l}\text { To study technology you have to be } \\
\text { talented. } \\
\end{array}$ \\
\hline $39+$ & $\begin{array}{l}\text { I could like a career in technology later } \\
\text { on. } \\
\text { سأر غب لاحقا في وظيفة تتضمن استخدام التكنولوجيا. }\end{array}$ & $\begin{array}{l}\text { I could like a career in technology later } \\
\text { on. } \\
\text { سأختار وظيفة في مجال التكنولوجيا لاحقا. }\end{array}$ \\
\hline $40^{*}$ & $\begin{array}{l}\text { I am not interested in technology. } \\
\text { أنا غير مهتم بالتكنولوجيا. }\end{array}$ & $\begin{array}{l}\text { I am not interested in technology. } \\
\text { أنا غير مهتم باستخدام التكنولوجيا. }\end{array}$ \\
\hline
\end{tabular}




\begin{tabular}{|c|c|c|}
\hline $\begin{array}{c}\text { Item } \\
\text { no. }\end{array}$ & Pre-panel of experts & After panel of experts \\
\hline $41^{*}$ & $\begin{array}{l}\text { Boys are more capable of doing } \\
\text { technological jobs than girls. } \\
\text { الفتيان أكثر قدرة على شغل وظائف قطاع التكنولوجيات الفتبات }\end{array}$ & $\begin{array}{l}\text { Boys are more capable of doing } \\
\text { technological jobs than girls. } \\
\text { الفتيان أكثر قدرة على شغل وظائف في استخدام التكنيات لفنيات. }\end{array}$ \\
\hline $42+$ & $\begin{array}{l}\text { Using technology makes a country less } \\
\text { prosperous. } \\
\text { استخدام التكنولوجيا يجعل البلد أقدارا. }\end{array}$ & $\begin{array}{l}\text { Using technology makes a country less } \\
\text { prosperous. } \\
\text { استخدام التكنولوجيا يجعل البلد أقدهار. }\end{array}$ \\
\hline $43 *$ & 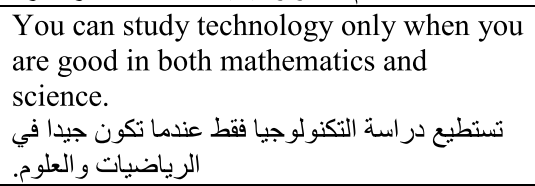 & $\begin{array}{l}\text { You can study technology only when you } \\
\text { are good in both mathematics and } \\
\text { science. } \\
\text { تسنطيع دراسة التكنولوجيا فقط عندما تكون جيداً والعلوم. }\end{array}$ \\
\hline $44^{*}$ & $\begin{array}{l}\text { There should be more education about } \\
\text { technology. }\end{array}$ & $\begin{array}{l}\text { There should be more education about } \\
\text { technology. } \\
\text { ينبغي أن يكون هناك تعليم أكثر عن استخدام }\end{array}$ \\
\hline $45^{*}$ & could be boring. & $\begin{array}{l}\text { Working in technology could be boring. } \\
\text { العمل في حقل استخدام التكنولوجيا ممل. }\end{array}$ \\
\hline $50+$ & $\begin{array}{l}\text { Technology as a subject should be taken } \\
\text { by all pupils. } \\
\text { ينبغي على جميع الطلاب دراسة التكنولوجيا تعليمة. }\end{array}$ & $\begin{array}{l}\text { Technology as a subject should be taken } \\
\text { by all pupils. } \\
\text { ينبغي على جميع التلاميذ دراسة التكنولوجيا تعليمة. }\end{array}$ \\
\hline $53+$ & $\begin{array}{l}\text { efer not to go to a technical } \\
\text { تفضل الفتيات عدم الذهاب إلى }\end{array}$ & $\begin{array}{l}\text { Girls prefer not to go to a technical } \\
\text { school. } \\
\text { تفضل الفتيات عدم الذهاب إلى كلية تدِرس التكنولوجيا. }\end{array}$ \\
\hline $56^{*}$ & $\begin{array}{l}\text { Technology lessons help you train for a } \\
\text { good job. }\end{array}$ & $\begin{array}{l}\text { Technology lessons help you train for a } \\
\text { good job. } \\
\text { الدروس التكنولوجية قد تساعدك في الإعداد لوظيفةٍة جيدة. }\end{array}$ \\
\hline $58 *$ & $\begin{array}{l}\text { ologica1 hobby is boring. } \\
\text { الهو اية التكنول }\end{array}$ & $\begin{array}{l}\text { A technologica1 hobby is boring. } \\
\text { الهو اية التكنولوجية ملة. }\end{array}$ \\
\hline $60 *$ & $\begin{array}{l}\text { Technology is the subject of the future. } \\
\text { التكنولوجيا مادة المستقبل. }\end{array}$ & $\begin{array}{l}\text { subject of the future. } \\
\text { التكنولو }\end{array}$ \\
\hline $62+$ & $\begin{array}{l}\text { Not everyone needs technology lessons at } \\
\text { school. } \\
\text { لا يحتاج جميع الناس لدروس التكنولوجيا في المدرسة. }\end{array}$ & $\begin{array}{l}\text { Not everyone needs technology lessons at } \\
\text { school. } \\
\text { ليس كل شخص يحتاج لدروس في استخدام التكنولوجيا }\end{array}$ \\
\hline $63^{*}$ & 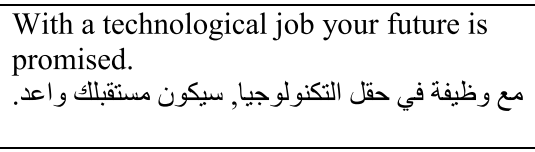 & $\begin{array}{l}\text { With a technological job your future is } \\
\text { promised. } \\
\text { سيكون مسنقبلك و اعداً بحصو للك على وظيفة فيكال مجنوليا. }\end{array}$ \\
\hline
\end{tabular}

\section{References}

Al-Issa, A. S. (2005). An ideological discussion of the impact of the NNESTs' English language knowledge on Omani ESL policy implementation. Retrieved March 5, 2019, from https://www.asian-efl-journal. 
$\mathrm{com} / \mathrm{main}$-journals/an-ideological-discussion-of-the-impact-of-the-nnests-english-language-knowl edge-on-esl-policy-implementation-a-special-reference-to-the-omani-context/

Al-Issa, A. S. (2006). The cultural and economic politics of English Language Teaching in Sultanate of Oman. The Asian EFL Journal Quarterly, 8(1), 194-218.

Al-Jarf, R. (2008). The impact of English as an International Language (EIL) upon Arabic in Saudi Arabia. Asian EFL Journal Quarterly, 10(4), 1-27.

Ankiewicz, P. (2019a). Perceptions and attitudes of pupils towards technology: In search of a rigorous theoretical framework. International Journal of Technology and Design Education, 29, 37-56.

Ankiewicz, P. (2019b). Alignment of the traditional approach of perceptions and attitudes with Mitcham's philosophical framework of technology. International Journal of Technology and Design Education, 29, 329-340.

Ardies, J., De Maeyer, S., \& Gijbels, D. (2013). Reconstructing the pupils attitude towards technology-survey. Design and Technology Education: An International Journal, 8(1), 8-19.

Ardies, J., De Maeyer, S., Gijbels, D., \& van Keulen, H. (2015). Students' attitudes towards technology. Design and Technology Education: An International Journal, 251, 43-65.

Bame, E. A., \& Dugger, W. E. (1990). Pupils' attitudes and concepts of technology. The Technology Teacher, 49(8), 10-11.

Bame, E. A., \& Dugger, W. E. (1992). Pupils' attitude towards technology: Executive summary of PATTUSA study. Paper presented at the ITEA-PATT International Conference. Reston, USA.

Bame, E. A., \& Dugger, W. E. (1989). pupils' attitude towards technology: PATT-USA. A Paper presented at PATT4 Conference: Teacher Education for School Technology. Eindhoven, The Netherlands.

Bame, E. A., Dugger, W. E., De Vries, M. J., \& McBee, J. (1993). Pupils' attitudes TowardsTechnology: PATT-USA. Journal of Technology Studies, 19(1), 40-48.

Becker, K. H., \& Maunsaiyat, S. (2002). Thai students' attitudes and concepts of technology. Journal of Technology Education, 13(2), 6-20.

Candela, P. P. (2019). The adaptation of the Attitude Behavioural Scale (ABS) of pupils' attitude towards technology instrument to design, construct, and validate the Technology Attitude Bilingual Scale (TABS-Arabic/English) for an Arabic context. Unpublished PhD thesis. Pretoria: University of South Africa.

Cohen, L., Manion, L., \& Morrison, K. R. B. (2005). Research methods in education. . Routledge.

Creswell, J.W. (2007). An introduction to mixed methods research. Retrieved May 27, 2020, from https:// www.researchgate.net/publication/237658796_An_Introduction_to_Mixed_Method_Research

Dakers, J. R., Dow, W., \& McNamee, L. (2009). De-constructing technology's masculinity: Discovering a missing pedagogy in Technology Education. International Journal of Technology and Design Education, 19, 381-391.

De Klerk, W. F. (1989). A PATT study among 10 to 12-year-old students in the Netherlands. Journal of Technology Education, 1(1), 21-31.

Evans, B. C., Coon, D. W., \& Ume, E. (2011). Use of theoretical frameworks as a pragmatic guide for mixed methods studies: A methodology necessity? Journal of Mixed Methods Research, 5(4), 276-292.

Findlow, S. (2006). Higher education and linguistic dualism in the Arab Gulf. British Journal of Sociology of Education, 27(1), 19-36.

Guest, G. (2012). Describing mixed methods research: An alternative to typologies. Journal of Mixed Methods Research, 7(2), 141-151.

Gumbo, M. T. (2018). Addressing the factors responsible for the misunderstanding of Technology Education with other subject fields. Perspectives in Education, 36(1), 128-144.

Gumbo, M.T. (2013). A bumpy ride - Curriculum change and its impact on Technology Education in South Africa: Voices from the academy. A Paper presented at the 75th International Technology and Engineering Educators Association Conference. Columbus, USA.

Jarvis, H. (2005). Technology and change in English Language Teaching (ELT). Asian EFL Journal Quarterly, 7(4), 213-227.

Jeffrey, T. J. (1993). Adaptation and validation of a technology attitude scale for use by American teachers at the middle school level. Unpublished $\mathrm{PhD}$ thesis. Blacksburg: Virginia Polytechnic Institute and State University.

Killean, C. (2004). Arabic. Encyclopaedia of the Modern Middle East and North Africa. Retrieved October 19, 2019, from http://www.encyclopedia.com/doc/1G2-3424600277.html

Kim, J. S. (2000). Students' attitudes and perceptions toward technology. Unpublished Doctoral Dissertation. Ames: Iowa State University.

Newman, D. (2002). The phonetic status of Arabic within the world's languages: the uniqueness the lughat al-daad. Antwerp Papers in Linguistics, 100, 65-75. 
Rennie, L. J. (1987). Teachers' and pupils' perceptions of technology and the implications for curriculum. Research in Science \& Technological Education, 5(2), 121-133.

Svenningsson, J., Hultén, M., \& Hallström, J. (2018). Understanding attitude measurement: Exploring meaning and use of the PATT short questionnaire. International Journal of Technology and Design Education, 28, 67-83.

Troudi, S. (2002). English as a language of instruction in the UAE. TESOL Arabia News, 9, 5-10.

Volk, K. S., \& Yip, W. M. (1999). Gender and technology in Hong Kong: A study of Pupils' Attitudes toward technology. International Journal of Technology and Design Education, 9, 57-71.

Publisher's Note Springer Nature remains neutral with regard to jurisdictional claims in published maps and institutional affiliations. 